\title{
ВПЛИВ ГЕНОТИПОВИХ ТА ПАРАТИПОВИХ ФАКТОРІВ НА СПЕРМОПРОДУКТИВНІСТЬ БУГАЇВ
}

\author{
Піддубна Людмила Михайлівна \\ доктор сільськогосподарських наук, доцент \\ Поліський національний університет \\ ORCID: 0000-0002-5893-8726 \\ E-mail: I.m.poddubnaya@gmail.com
}

Захарчук Дар'я Валеріївна аспірантка

Поліський національний університет ORCID: 0000-0003-3026-4253

E-mail: dashazt781@gmail.com

\begin{abstract}
Досліджено вплив генотипових та паратипових фракторів на спермопродуктивність голштинських бугаїв чорно- і червоно-рябої масті ТОВ «Українська генетична компанія» Житомирської області. Плідники були завезені з Німеччини та Нідерландів і перебували в однакових умовах годівлі, утримання та використання. Якісні та кількісні показники спермопродукції визначали з використанням аналізатора сім'я IVOS (система CASA). Оцінку нативної сперми проводили за ДСТУ 3535-97. Силу фракторів впливу на показники спермопродуктивності бугаїв визначали однофакторним дисперсійним аналізом. Піддослідні бугаї в умовах ТОВ «Українська генетична компанія» загалом характеризуються високим відтворювальним потенціалом. Упродовж року від них отримано в середньому 106,4 якісних еякуляти, 542,0 мл якісної нативної сперми та $28361 \mathrm{~mm}$. спермодоз. Річні показники спермопродуктивності виявилися досить варіабельними $\left(C_{v}=9,2-60,8\right.$ \%), що засвідчує значні індивідуальні особливості плідників. Кількість отриманих якісних еякулятів коливається в межах 32-173 шт., нативної сперми - 201-1016 мл, отриманих спермодоз - 5755-61920 шт. Об'єму еякуляту становить 3,77-7,30 мл, концентрація сперміїв в еякуляті - 1,51-3,52 млрд/мл, їх рухливість - 7,2-8,3 бала. Результати досліджень свідчать про вагомий вплив генетичних фракторів на фрормування спермопродуктивності голштинських плідників. Від генотипу бугая та його адаптаційних можливостей більш ніж на 40 \% залежить кількість та якість отриманих еякулятів і вихід спермодоз. Лінійна належність плідника значною мірою впливає на об'єм еякуляту (19,3 \%) та концентрацію сперми (30,6 \%). Кожна лінія вірогідно відрізняється за більшістю досліджених показників спермопродуктивності та має свої особливості. Частки впливу масті та еколого-генетичного походження бугая на кількісні і якісні показники сперми мінімальні (0,2-2,5%). Виявлена сезонна динаміка спермопродуктивності голштинських бугаїв. Пік статевої активності припадає на весняний сезон - 31,6 шт. якісних еякулятів $(P<0,05)$ та 158,0 мл нативної сперми $(P>0,05)$ від одного бугая. Найбільший вихід спермодоз спостерігається у зимово-весняний період - 7851-8069 шт., найменший у літньо-осінній - 6149-6293 шт. Більші за об'ємом еякуляти зафріксовано влітку та восени - 5,23-5,28 мл, менші взимку та навесні - 4,90-5,00 (P<0,001). Рухливість сперміїв в еякулятах вища у холодну пору року (осінь-зима) - 7,9-8,0 бала, нижча у теплу (весна-літо) - 7,4-7,7 бала ( $P<0,001)$. Сила впливу сезону року на відтворну функцію бугаїв складає 0,8-9,3\%.
\end{abstract}

Ключові слова: бугаї-плідники, голштинська порода, спермопродуктивність, генотип, лінія, сезон року, сила впливу.

DOI: https://doi.org/10.32845/bsnau.lvst.2020.2.10.

Одним з важливих завдань сільського господарства $€$ пошук шляхів збільшення виробництва продукції тваринництва. Це можливо завдяки інтенсифікації галузі скотарства та підвищенню генетичного потенціалу продуктивності великої рогатої худоби.

Створення високопродуктивних молочних стад базується на використанні для відтворення маточного поголів'я бугаїв-плідників з високою племінною цінністю. Їх вплив на генетичне поліпшення племінних та продуктивних якостей корів становить близько 90 \% [2]. Впровадження в широку практику методу штучного осіменіння й тривалого зберігання кріоконсервованої сперми дало можливість інтенсивно використовувати бугаїв-поліпшувачів та отримувати від них велику кількість висопродуктивних потомків [2]. Результати штучного осіменіння, головним чином, залежать від репродуктивних якостей тварин [16], тому при оцінці та відборі плідників велику увагу звертають на їх статеву активність, кількість та якість отриманої сперми, її запліднювальну здатність. Найкращий за походженням та екстер'єром бугай має племінну цінність тільки тоді, коли у нього високі показ- ники відтворної здатності [5].

Результати наукових досліджень $[3,8,23]$ вказують на суттєву мінливість спермопродуктивності бугаївплідників, спричинену цілим рядом фракторів, як генотипових, так і паратипових. Про вплив індивідуальних, породних та лінійних особливостей бугаїв на кількісні та якісні показники сперми свідчать численні дослідження $[6,7,12,14,19]$. Й. 3. Сірацьким та співавторами [13] встановлено, що вплив віку бугаїв на об'єм еякуляту залежно від породи становить в межах 24,2-30,1 \%, концентрацію сперміїв - 2,6-15,2 \%, їх рухливість - 4,3-18,3, стійкість сперміїв до заморожування 8,5-15,8 \%. У науковій літературі немає єдиної думки щодо впливу сезону року на показники спермопродуктивності бугаїв-плідників. Boujenane et al [15], Mathevon et al. [20] спостерігали високі показники спермопродукції у голштинських бугаїв у зимовий та весняний період, низькі - влітку. Murphy E. M. et al. [22], Snoj et al. [24] відмічають максимальні показники об'єму еякуляту та концентрації сперміїв у літній сезон. Кузебний С. В. [9] не виявив сезонної зміни спермопродуктивності у бугаїв голштинської та споріднених Вісник Сумського національного аграрного університету 
3 нею вітчизняних порід. Мінливість спермопродуктивності упродовж року може бути спричинена коливанням температури і вологості повітря навколишнього середовища, зміною тривалості світлової частини доби, перепадами атмосферного тиску, тощо $[4,18,21]$. Досить важливими елементами при виробництві якісної сперми є умови годівлі та утримання плідників, а також режим використання $[17,20]$.

Краще розуміння дії цих факторів на кількісні та якісні показники спермопродукції дозволить племпідприємствам ефективно організувати роботу з бугаями-плідниками та збільшити від них вихід якісної сперми.

У зв'язку з цим, метою наших досліджень є вивчення впливу генотипових та паратипових фракторів на спермопродуктивність голштинських бугаїв-плідників в умовах ТОВ «Українська генетична компанія»

Матеріали та методи досліджень. Дослідження проведені на поголів'ї 20 голштинських бугаїв-плідників чорно- і червоно-рябої масті віком від 3-12 років. Плідники були завезені на племпідприємство із Німеччини та Нідерландів.

Тварини знаходились в однакових умовах годівлі, утримання та використання. До щоденного раціону плідників в зимній період входить: червона морква, кормові буряки, сіно злаково-бобове, спецкомбікорм бугаїв-плідників ПК 66448/19, яйця курячі, цукор, сіль лизунець. Влітку частину сіна замінюють на прив'ялену злаково-бобову траву і виключають коренеплоди.

Бугаїв-плідників утримують безприв'язно, в окремих індивідуальних клітках розміром 2,5х1,8 м, на дерев'яній підлозі при температурі та вологості повітря відповідно до зоогігієнічних вимог. У літній період (вдень) бугаїв утримують на вигулі під навісом, де обладнаний кільцевий коридор з металевих труб, у якому вони рухаються самостійно. Загальна відстань проходження при моціоні складає 3-4 км за день.

Сперму одержують з допомогою штучної вагіни двічі на тиждень шляхом дуплетної садки на підставного бугая. Одразу після виділення бугаєм сперми взятий еякулят герметизують і через стерильний шлюз передають у лабараторію, де проходить оцінка спермопродукції.

Матеріалом для досліджень слугували відомості обліку одержаної сперми від бугаїв-плідників, форма № 1-мол. «Картка племінного бугая», а також результати власних лабораторних досліджень.

Об'єм еякуляту, концентрацію сперміїв в 1 мл сперми та рухливість сперміїв визначали на аналізаторі сім'я IVOS (система CASA). Оцінку якості нативної сперми проводили за ДСТУ 3535-97. Силу впливу генотипових і паратипових факторів на спермопродуктивність бугаїв визначали однофракторним дисперсійним аналізом [10]. Обробку первинних даних проводили методами варіаційної статистики, використовуючи комп'ютерну програму "MS Office Excel 2010".

Результати досліджень. Ефективність роботи та величину прибутку племінних підприємств визначає вихід заморожених спермодоз від плідників. Цей показник обумовлений насамперед кількістю та якістю отриманих еякулятів від бугаїв.

Дослідженнями встановлено, що голштинські бугаїплідники в умовах ТОВ «Українська генетична компанія» характеризуються досить високими показниками спермопродуктивності - упродовж року від них отримано в середньому 106,4 якісних еякуляти, 542,0 мл якісної нативної сперми та 28361 шт. спермодоз (табл. 1).

Таблиця 1

Середнє значення та варіація річних показників спермопродуктивності голштинських бугаїв-плідників (n=20)

\begin{tabular}{|l|c|c|c|c|}
\hline \multicolumn{1}{|c|}{$\begin{array}{c}\text { Показник, } \\
\text { одиниці виміру }\end{array}$} & $\mathbf{M \pm m}$ & $\lim$ & $\mathbf{C}_{\mathbf{v}} \%$ \\
\hline Отримано еякулятів, шт. & $106,4 \pm 9,32$ & $32-173$ & 41,70 & 39,2 \\
\hline Отримано нативної сперми, мл & $542,0 \pm 52,84$ & $201-1016$ & 236,32 & 43,6 \\
\hline Об'єм еякуляту, мл & $5,09 \pm 0,037$ & $3,77-7,30$ & 1,689 & 33,2 \\
\hline Концентрація сперміїв, млрд/мл & $2,57 \pm 0,018$ & $1,51-3,52$ & 0,848 & 33,0 \\
\hline Рухливість сперміїв, бали & $7,8 \pm 0,02$ & $7,2-8,3$ & 0,72 & 9,2 \\
\hline Отримано спермодоз, шт. & $28361 \pm 3856$ & $5755-61920$ & 17247 & 60,8 \\
\hline
\end{tabular}

При цьому бугаї в однакових умовах утримання і використання значно відрізняються за показниками спермопродуктивності та якості спермопродукції. Кількість отриманих еякулятів від плідника коливається в межах 32-173 шт., отриманої нативної сперми - 201-1016 мл, спермодоз 5755-61920 шт., об'єм еякуляту в межах 3,77-7,30 мл, концентрація сперміїв в еякуляті - 1,51-3,52 млрд/мл, їх рухливість - 7,2-8,3 бала. Найстабільнішим показником є рухливість сперміїв ( $\left.\mathrm{C}_{\mathrm{v}}=9,2 \%\right)$, найбільш мінливим - вихід спермодоз $\left(\mathrm{C}_{\mathrm{v}}=60,8 \%\right)$. Це свідчить про значні індивідуальні особливості піддослідних плідників, тобто вони суттєво різняться за відтворювальним потенціалом і адаптаційною здатністю.

На показники спермопродуктивності голштинських бугаїв-плідників впливає також їхня лінійна належність (табл. 2). У дослідженні не враховано лінії, що представлені одним бугаєм.

Лідерами за виходом спермодоз (понад 42 тис. шт.) виявилися представники лінії Чіфа. Вони мають найвищу статеву активність (140 якісних еякулятів упродовж року), високі показники концентрації сперміїв в 1 мл (понад 3 млрд) та рухливості сперміїв (8 балів). На другому місці опинилися бугаї лінії Елевейшна із річним виходом спермодоз 35 тис. шт. Вони характеризуються максимальним об'ємом еякуляту (5,86 мл) і найбільшою серед усіх ліній кількістю отриманої сперми (673,8 мл). Бугаї ліній Астронавта та Джоско Бесна за більшістю досліджуваних показників вірогідно не відрізняються і мають річний вихід спермодоз в межах 26 тис. шт. Мінімальну кількість якісних еякулятів і відповідно найменше спермодоз упродовж року (біля 19 тис. шт) отримано від плідників лінії Старбака. 
Таблиця 2

Річні показники спермопродуктивності голштинських бугаїв-плідників залежно від лінійної належності

\begin{tabular}{|c|c|c|c|c|c|c|}
\hline \multirow{3}{*}{$\begin{array}{c}\text { Показник, } \\
\text { одиниці виміру }\end{array}$} & \multicolumn{5}{|c|}{ Лінія } & \multirow{3}{*}{$\begin{array}{l}\text { Різниця } \\
\text { (max-min) }\end{array}$} \\
\hline & $\begin{array}{l}\text { Астронавта } \\
1458744.64\end{array}$ & $\begin{array}{c}\text { Джоско Бесна } \\
5694028588.94\end{array}$ & $\begin{array}{l}\text { Елевейшна } \\
1491007.65\end{array}$ & $\begin{array}{r}\text { Старбака } \\
352790.79\end{array}$ & $\begin{array}{c}\text { Uiфpa } \\
1427381.62\end{array}$ & \\
\hline & 2 & 2 & 6 & 4 & 3 & \\
\hline Отримано еякулятів, шт. & $\begin{array}{c}111,5 \\
\pm 49,50\end{array}$ & $\begin{array}{l}113,5 \\
\pm 8,50\end{array}$ & $\begin{array}{c}114,8 \\
\pm 22,16\end{array}$ & $\begin{array}{c}86,2 \\
\pm 12,72\end{array}$ & $\begin{array}{r}140,6 \\
\pm 7,36\end{array}$ & $54,4 \pm 14,70^{\star \star *}$ \\
\hline Отримано нативної сперми, мл & $\begin{array}{c}560,0 \\
\pm 257,00\end{array}$ & $\begin{array}{r}599,2 \\
\pm 1,50\end{array}$ & $\begin{array}{c}673,8 \\
\pm 133,40\end{array}$ & $\begin{array}{c}358,5 \\
\pm 39,63\end{array}$ & $\begin{array}{c}599,0 \\
\pm 19,00\end{array}$ & $315,3 \pm 139,20^{*}$ \\
\hline Об’єм еякуляту, мл & $\begin{array}{c}5,02 \\
\pm 0,105\end{array}$ & $\begin{array}{c}5,28 \\
\pm 0,095\end{array}$ & $\begin{array}{c}5,86 \\
\pm 0,062\end{array}$ & $\begin{array}{c}4,15 \\
\pm 0,078\end{array}$ & $\begin{array}{c}4,25 \\
\pm 0,059\end{array}$ & $1,71 \pm 0,099^{* * *}$ \\
\hline Концентрація сперміїв, млрд/мл & $\begin{array}{c}2,24 \\
\pm 0,041 \\
\end{array}$ & $\begin{array}{c}2,17 \\
\pm 0,027 \\
\end{array}$ & $\begin{array}{c}2,70 \\
\pm 0,032 \\
\end{array}$ & $\begin{array}{c}2,11 \\
\pm 0,025 \\
\end{array}$ & $\begin{array}{c}3,34 \\
\pm 0,039 \\
\end{array}$ & $1,29 \pm 0,046^{\star \star *}$ \\
\hline Рухливість сперміїв, бали & $\begin{array}{c}7,6 \\
\pm 0,03\end{array}$ & $\begin{array}{c}7,4 \\
\pm 0,03\end{array}$ & $\begin{array}{c}7,9 \\
\pm 0,03\end{array}$ & $\begin{array}{c}7,6 \\
\pm 0,03\end{array}$ & $\begin{array}{c}8,0 \\
\pm 0,04\end{array}$ & $0,6 \pm 0,048^{* * *}$ \\
\hline Отримано спермодоз, шт. & $\begin{array}{r}26450 \\
\pm 19725\end{array}$ & $\begin{array}{l}26300 \\
\pm 5435\end{array}$ & $\begin{array}{l}35005 \\
\pm 9318\end{array}$ & $\begin{array}{r}18991 \\
\pm 4505\end{array}$ & $\begin{array}{r}42780 \\
\pm 7843\end{array}$ & $23789 \pm 9044^{* *}$ \\
\hline
\end{tabular}

Порівняльне вивчення спермопродуктивності бугаїв різної масті (табл. 3) засвідчило перевагу чорно-рябих плідників за концентрацією сперміїв в 1 мл $(+0,19$ млрд, $\mathrm{P}<0,001)$ та рухливістю сперміїв в еякулятах $(+0,2$ бала,
$\mathrm{P}<0,001)$, як наслідок від них отримали упродовж року на 6249 спермодоз більше. Перевага бугаїв червоно-рябої масті - більші за об'ємом еякуляти $(+0,20, \mathrm{P}<0,001)$.

Річні показники спермопродуктивності голштинських

Таблиця 3 бугаїв-плідників залежно від масті (M士m)

\begin{tabular}{|c|c|c|c|}
\hline \multirow{2}{*}{$\begin{array}{c}\text { Показник, } \\
\text { одиниці виміру } \\
\end{array}$} & \multicolumn{2}{|c|}{ Масть бугая } & \multirow{3}{*}{$\begin{array}{l}\text { Різниця } \\
(\mathrm{d} \pm \mathrm{md})\end{array}$} \\
\hline & чорно-ряба & червоно-ряба & \\
\hline Кількість бугаїв, гол & 12 & 8 & \\
\hline Отримано еякулятів, шт. & $108,2 \pm 12,72$ & $103,6 \pm 14,39$ & $+4,6 \pm 19,20$ \\
\hline Отримано нативної сперми, мл & $543,0 \pm 74,44$ & $540,6 \pm 76,73$ & $+2,4 \pm 106,9$ \\
\hline Об'єм еякуляту, мл & $5,01 \pm 0,046$ & $5,21 \pm 0,058$ & $-0,20 \pm 0,074^{* * *}$ \\
\hline Концентрація сперміїв, млрд/мл & $2,65 \pm 0,024$ & $2,46 \pm 0,027$ & $+0,19 \pm 0,036^{* * *}$ \\
\hline Рухливість сперміїв, бали & $7,8 \pm 0,02$ & $7,6 \pm 0,02$ & $+0,2 \pm 0,03^{* * *}$ \\
\hline Отримано спермодоз, шт. & $30860 \pm 5449$ & $24611 \pm 5252$ & $+6249 \pm 7568$ \\
\hline
\end{tabular}

Відтворна здатність бугаїв $є$ індикатором їх адаптаційних можливостей та стресостійкості $[1,11]$. Плідники різного генетико-екологічного походження характеризуються достатньою статевою активністю та спермопродуктивністю в нових господарсько-кліматичних умовах. Упродовж року від них отримано у середньому 105,6-108,8 шт. якісних еякулятів, 504,4-554,6 мл якісної нативної сперми та заморожено 26903-28847 спермодоз (Р>0,05) (табл. 4).

Таблиця 4

Річні показники спермопродуктивності голштинських бугаїв-плідників залежно від походження (M士m)

\begin{tabular}{|l|c|c|c|}
\hline \multicolumn{1}{|c|}{$\begin{array}{c}\text { Показник, } \\
\text { одиниці виміру }\end{array}$} & Країна походження & \multirow{2}{*}{$\begin{array}{c}\text { Різниця } \\
(\mathrm{d} \pm \mathrm{md})\end{array}$} \\
\cline { 2 - 3 } & Німеччина & Нідерланди & $-3,2 \pm 20,27$ \\
\hline Кількість бугаїв, гол & 15 & $108,8 \pm 16,75$ & $+50,2 \pm 112,3$ \\
\hline Отримано еякулятів, шт. & $105,6 \pm 11,42$ & $504,4 \pm 91,65$ & $+0,62 \pm 0,075^{\star * *}$ \\
\hline Отримано нативної сперми, мл & $554,6 \pm 64,87$ & $4,63 \pm 0,062$ & $+0,09 \pm 0,037^{*}$ \\
\hline Об'єм еякуляту, мл & $5,25 \pm 0,043$ & $2,50 \pm 0,030$ & $+0,1 \pm 0,030^{\star *}$ \\
\hline Концентрація сперміїв, млрд/мл & $2,59 \pm 0,022$ & $7,7 \pm 0,024$ & $+1944 \pm 8059$ \\
\hline Рухливість сперміїв, бали & $7,8 \pm 0,019$ & $26903 \pm 6491$ & \\
\hline Отримано спермодоз, шт. & $28847 \pm 4778$ & \\
\hline
\end{tabular}

При цьому плідники німецької селекції вірогідно переважають голландських за об'ємом еякуляту $(+0,62$ мл, Р<0,001), концентрацією сперміїв в 1 мл $(+0,09$ млрд, $P<0,05)$ та рухливістю сперміїв в еякулятах $(+0,1$ бала, $P<0,01)$.

Більшість дослідників відмічають, що важливим фрактором, який впливає на спермопродуктивність бугаїв, $€$ сезон року. Виявлена нами динаміка сезонних змін характеризується суттєвим збільшенням статевої активності плідників невесні (табл. 5).
За весняний сезон одержано максимальну кількість якісних еякулятів від одного бугая $(31,6$ шт., $P<0,05)$ та нативної сперми $(158,0$ мл, $\mathrm{P}>0,05)$. У інші пори року названі показники склали 24,3-26,1 шт. і 127,8-128,2 відповідно.

Найбільшу кількість спермодоз заморожено у зимово-весняний сезон -7851-8069 шт. від одного плідника. Об'єм еякуляту у цей період становив 4,90-5,00 мл, концентрація сперміїв в 1 мл - 2,52-2,53 млрд, рухливість сперміїв в еякулятах була вищою взимку (+0,3 бала, $P<0,001)$. 
Показники спермопродуктивності голштинських

бугаїв-плідників залежно від сезону року $(\mathrm{n}=20)$

\begin{tabular}{|c|c|c|c|c|c|}
\hline \multirow{2}{*}{ Показник, одиниці виміру } & \multicolumn{4}{|c|}{ Сезон року } & \multirow{3}{*}{$\begin{array}{l}\text { Різниця } \\
\text { (max-min) }\end{array}$} \\
\hline & зима & весна & літо & осінь & \\
\hline Отримано всього еякулятів, шт. & 522 & 631 & 485 & 490 & \\
\hline $\begin{array}{l}\text { Отримано у середньому еякулятів від одного } \\
\text { бугая за сезон, шт. }\end{array}$ & $\begin{array}{c}26,1 \\
\pm 2,59\end{array}$ & $\begin{array}{r}31,6 \\
\pm 2,65\end{array}$ & $\begin{array}{c}24,3 \\
\pm 2,59\end{array}$ & $\begin{array}{c}24,5 \\
\pm 3,06\end{array}$ & $7,3 \pm 3,71^{*}$ \\
\hline Отримано всього нативної сперми, мл & 2556,5 & 3160,2 & 2560,3 & 2564,3 & \\
\hline $\begin{array}{l}\text { Отримано у середньому нативної сперми від } \\
\text { одного бугая за сезон, мл }\end{array}$ & $\begin{array}{c}127,8 \\
\pm 14,43\end{array}$ & $\begin{array}{r}158,0 \\
\pm 15,08\end{array}$ & $\begin{array}{r}128,0 \\
\pm 14,27\end{array}$ & $\begin{array}{r}128,2 \\
\pm 15,20\end{array}$ & $30,2 \pm 20,9$ \\
\hline Об’єм еякуляту, мл & $\begin{array}{c}4,90 \\
\pm 0,069\end{array}$ & $\begin{array}{c}5,00 \\
\pm 0,067\end{array}$ & $\begin{array}{c}5,28 \\
\pm 0,081\end{array}$ & $\begin{array}{c}5,23 \\
\pm 0,077\end{array}$ & $0,38 \pm 0,106^{* * *}$ \\
\hline Концентрація сперміїв, млрд/мл & $\begin{array}{c}2,52 \\
\pm 0,034 \\
\end{array}$ & $\begin{array}{r}2,53 \\
\pm 0,032 \\
\end{array}$ & $\begin{array}{c}2,78 \\
\pm 0,042 \\
\end{array}$ & $\begin{array}{c}2,47 \\
\pm 0,039 \\
\end{array}$ & $0,31 \pm 0,057^{* * *}$ \\
\hline Рухливість сперміїв, бали & $\begin{array}{c}8,0 \\
\pm 0,033\end{array}$ & $\begin{array}{c}7,7 \\
\pm 0,026\end{array}$ & $\begin{array}{c}7,4 \\
\pm 0,022\end{array}$ & $\begin{array}{c}7,9 \\
\pm 0,037\end{array}$ & $0,6 \pm 0,039^{* * *}$ \\
\hline Отримано спермодоз, шт. & 161375 & 157010 & 125855 & 122975 & \\
\hline $\begin{array}{l}\text { Отримано у середньому спермодоз від одного } \\
\text { бугая за сезон, шт. }\end{array}$ & $\begin{array}{c}8069 \\
\pm 1458\end{array}$ & $\begin{array}{c}7851 \\
\pm 1019\end{array}$ & $\begin{array}{l}6293 \\
\pm 979\end{array}$ & $\begin{array}{c}6149 \\
\pm 1016\end{array}$ & $1920 \pm 1777$ \\
\hline
\end{tabular}

У літньо-осінній період від бугаїв одержано в середньому на 7 еякулятів та 30 мл нативної сперми менше порівняно з весняним сезоном ( $\mathrm{P}<0,05 \ldots>0,05)$, внаслідок чого отримано меншу кількість спермодоз - 6149-6293 шт. Натомість влітку прослідковуються максимальні об'єм еякуляту $(5,28$ мл, $\mathrm{P}<0,001 \ldots>0,05)$ та концентрація сперміїв в 1 мл (2,78 млрд, $\mathrm{P}<0,001)$, що може бути пов'язано із згодовуванням бугаям прив'яленої зеленої маси.

Таблиця 5

Більший об'єм еякулятів зафріксовано влітку та восени - 5,23-5,28 мл, менший взимку та навесні - 4,90-5,00 (P<0,001), вища рухливість сперміїв в еякулятах у холодну пору року (осінь-зима) - 7,9-8,0 бала, нижча у теплу (весналіто) - 7,4-7,7 бала $(P<0,001)$.

За результатами дисперсійного аналізу встановлено сила впливу різних фракторів на показники спермопродуктивності голштинських бугаїв-плідників (табл. 6).

Таблиця 6

Сила впливу генетичних і паратипових факторів на ознаки спермопродуктивності бугаїв-плідників

\begin{tabular}{|c|c|c|c|c|c|}
\hline \multirow[b]{2}{*}{ Фактор впливу } & \multicolumn{5}{|c|}{ Показники } \\
\hline & отримано еякулятів & об'єм еякуляту & $\begin{array}{c}\text { концентрація } \\
\text { сперміїв }\end{array}$ & $\begin{array}{c}\text { рухливість } \\
\text { сперміїв }\end{array}$ & вихід спермодоз \\
\hline Індивідуальні особливості бугая & $52,1^{\text {***}}$ & $43,5^{\star \star \star}$ & $46,9^{\star \star *}$ & $21,9^{\star \star *}$ & $48,8^{\star \star \star}$ \\
\hline Лінія & $5,5^{*}$ & $19,3^{* * *}$ & $30,6^{* * *}$ & $8,7^{\star * \star}$ & $9,6^{\star \star *}$ \\
\hline Масть & 0,8 & $0,3^{* *}$ & $1,2^{\star \star *}$ & $2,3^{\star * *}$ & $1,8^{*}$ \\
\hline Країна походження плідника & 0,9 & $2,5^{\star \star *}$ & $0,2^{*}$ & $0,4^{* *}$ & 0,0 \\
\hline Сезон року & $3,7^{*}$ & $0,8^{* \star *}$ & $1,8^{* \star *}$ & $9,3^{* * *}$ & 2,7 \\
\hline
\end{tabular}

Серед досліджених факторів найбільший вплив (21,9$52,1 \%$ ) на відтворювальну здатність бугаїв чинять їхні індивідуальні особливості. Частка впливу лінійної належності бугая на показники спермопродуктивності є теж суттєвою (5,5-30,6 $\%)$, особливо на об'єм еякуляту (19,3\%) та концентрацію сперміїв в еякуляті (30,6 \%). Виявлено незначний, але високовірогідний вплив масті та сезону року на концентрацію сперміїв в 1 мл (1,2 і 1,8 \% відповідно) та рухливість сперміїв в еякуляті (2,3 і 9,2 \% відповідно). Від місця народження плідника на 2,5 \% залежить об'єм еякуляту.

Висновки. 1. Генетичні фактори $€$ домінуючими у формуванні спермопродуктивності бугаїв-плідників.

2. Найбільший вплив (21,9-52,1%) на відтворювальну здатність бугаїв чинять їхні індивідуальні біологічні особливості. Саме від генотипу бугая та його адаптаційних можливостей на 40 \% і більше залежать такі показники як кількість і об'єм еякулятів, концентрація сперміїв в 1 мл та вихід спермодоз

3. Частка впливу лінійної належності на показники спермопродуктивності плідників складає 5,5-30,6 \%. Найбі- льша зумовленість лінією концентрації сперміїв в 1 мл (30,6 \%) та об'єму еякуляту (19,3%). Бугаї різних ліній вірогідно відрізняються за статевою активністю, спермопродуктивністю та якісними показниками спермопродукції.

4. Масть бугаїв-плідників не впливає на їхню статеву активність, але чинить незначний вплив на якісні показники спермопродукції (0,3-2,3 \%) та вихід спермодоз (1,8 \%).

5. Походження бугаїв також має деякий вплив на якісні показники спермопродукції (0,2-2,5 \%), проте кількість отриманих еякулятів та спермодоз $є$ практично однаковою у бугаїв, завезених з різних країн.

6. Виявлено сезонні зміни спермопродуктивності бугаїв-плідників. Максимум статевої активності спостерігається весною, найбільшу кількість еякулятів та спермодоз отримано у зимово-весняний період. Частка впливу сезону на якісні показники спермопрдукції становить 0,8-9,3 \% зумовлює їх динаміку упродовж року : більший об'єм еякуляту зафіксовано влітку та восени, менший - взимку та навесні, вища рухливість сперміїв у холодну пору року (осіньзима), нижча - у теплу (весна-літо). 


\section{Список використаної літератури:}

1. Анбаза Ю.В. Адаптационные способности импортированых быков-спермодоноров голштинской породы красно-пестрой популяции в ОАО «КРАСНОЯРСКАГРОПЛЕМ». Вестник Красноярского государственного аграрного универcumema. 2017. C. 174-180.

2. Басовський Н. 3., Рудик І. А., Буркат В. П. Вирощування, оцінка і використання плідників. К.: Урожай, 1992. 216

C.

3. Бойко О. В., Коропець Л. А. Спермопродуктивність і фізіологічні та морфологічні параметри сперми голштинських бугаїв. Науковий журнал «Тваринниитво та технології харчових продуктів». 2016. №236.С. 116-120.

4. Влияние перепадов атмосферного давления на характеристики семени быков-производителей/ Абилов А. И. и др. 2016. Зоотехния. №8. С. 23-32.

5. Эрнст Л. К., Жигачев А. И. Мониторинг генетических болезней животных в системе крупномасштабной селекции. М., 2006. 383 с.

6. Зенков П. М., Топурия Л. Ю. Влияние генотипа на показатели спермопродукции быков-производителей. Известия ОГАУ. 2014. № 3. С. 103-105.

7. Кава С.Й., Дмитрів О. Я., Остапів Д. Д., Яремчук І. М. Індивідуальні особливості якості еякулятів бугаїв. Науковий вісник ЛНУВМБТ ім. Ґжицького . 2011. №4(50). Т. 13. Ч. 2. С. 76-79.

8. Коропець Л. А., Свідро І. Г. Спермопродуктивність бугаїв-плідників голштинської породи різної масті. Збірник наукових праць “Технологія виробництва і переробки продукції тваринництва”. 2013. Вип. 21. С. 139-141.

9. Кузебний С. В. Вплив генетичних та паратипових фракторів на відтворювальну здатність бугаїв-плідників : автореф. дис. канд. с.-г. наук : 06.02 .01 - розведення та селекція тварин. УААН. Ін-т розведення і генетики тварин. с. Чубинське, 2008. $20 \mathrm{c}$.

10. Плохинский Н. А. Биометрия. Москва : Изд-во МГУ, 1970. 367 с

11. Пришедько В. М. Спермопродуктивність і якість сперми бугаїв-плідників різного рівня стресостійкості. Вісник аграрної науки Причорномор'я. 2010. Вип. 1. С.113-119.

12. Сірацький Й. З., Федорович Є. І., Федорович В. В. Відтворна здатність бугаїв різних ліній західного внутрішньопородного типу української чорно-рябої молочної породи. Розведення і генетика тварин: матеріали наукової дискусії «Розведення С.-г. тварин за лініями». К.: Аграрна наука, 2005. Вип. 38. С. 189-192.

13. Фізіолого-біохімічні та біотехнологічні показники сперми бугаӥв-плідників/ Сірацький Й. З., Федорович Є. І., Федорович В. В., Кадиш В. О., Піддубна Л. М. Київ: Люксар, 2008. 208 с.

14. Хмельниччий Л. М., Єрош Ю. О., Біба А. А. Вплив генетипових та паратипових чинників на якість спермопродукції бугаїв-плідників. Вісник СНАУ. Серія «Тваринниитво». 2011. Вип.7(18). С. 29-32.

15. Boujenane I. and Boussaq K.. 2013. Environmental effects and repeatability estimates for sperm production and semen quality of Holstein bulls. Archiv. Tierzucht. 56:1-6. doi:10.7482/0003-9438-56-096

16. Flowers W.L. Sperm characteristics that limit success of fertilization. J. Anim. 2013. V. 91. no. 73022-3029.

17. Heinrich Bollwein, Fredi Janett, Martin Kaske. (2017). Effects of nutrition on sexual development of bulls. Anim. Reprod., v.14, n.3, p.607-613. doi: 10.21451/1984-3143-AR1004

18. Igna V, Moje A, Mircu C, Roman M, Ghiurca C, Casalean D, Cernescu H. The influence of some environmental factors and age on semen production of Fleckvieh bulls. Lucrări Ştiintifice Medicină Veterinară. 2010; XLIII(2):5663.

19. Karoui S, Diaz C, Serrano M, Cue R, Celorrio I, Carabano MJ. Time trends, environmental factors and genetic basis of semen traits collected in Holstein bulls under commercial conditions. Anim Reprod Sci. 2011;124:28-38

20. Mathevon, M., Buhr, M.M., Dekkers, J.C.M., 1998. Environmental, management, and genetic factors affecting semen production in Holstein bulls. J. Dairy Sci. 81, 3321-3330. doi.org/10.3168/jds.S0022-0302(98)75898-9

21. M.G.M. Chacur, K.T. Mizusaki, L.R.A. Gabriel Filho, et al. 2013. Seasonal Effects on Semen and Testosterone in Zebu and Taurine Bulls. Acta Scientiae Veterinariae. 41: 1110.

22. Murphy EM, Kelly AK, O'Meara C, Eivers B, Lonergan P, Fair S. Influence of bull age, ejaculate number, and season of collection on semen production and sperm motility parameters in Holstein Friesian bulls in a commercial artificial insemination centre. J Anim Sci. 2018 Jun 4;96(6): 2408-2418. doi: 10.1093/jas/sky130. PMID: 29767722; PMCID: PMC6095274.

23. Mussabekov AT, Borovikov SN, Suranshiyev ZhA, Shamshidin AS (2016) Comparative Analysis of Holstein, BlackMotley, Angler, Simmental Bulls Semen. J Aquac Res Development 7: 395. doi:10.4172/2155-9546.1000395

24. Snoj T., Kobal S., and Majdic G.. 2013. Effects of season, age, and breed on semen characteristics in different bos taurus breeds in a 31-year retrospective study. Theriogenology. 79:847-852. doi:10.1016/j.theriogenology.2012.12.014

\section{References:}

1. Anbaza, Yu. V., 2017. Adaptatsionnye sposobnosti importirovanykh bykov-spermodonorov golshtinskoy porody krasnopestroy populyatsii v OAO «KRASNOYARSKAGROPLYEM» [Adaptation abilities of imported bulls-sperm donors of Holstain breed of red-motley population in the ISC «Krasnoyarsk agricultural breeding establishment]. Vestnik Krasnoyarskogo gosudarstvennogo agrarnogo universiteta, pp. 174-180.

2. Basovskyi, N. Z., Rudyk, I. A. and Burkat, V. P., 1992. Vyroshchuvannia, otsinka i vykorystannia plidnykiv [Raising, evaluation and using of sires]. K.: Urozhaj. 